\title{
Synthesis, characterization, crystal structures and computational studies on novel cyrhetrenyl hydrazones
}

(1)

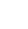

.

(1)

Johana Gómez ${ }^{\mathrm{a}}$, Nelson Leiva ${ }^{\mathrm{a}}$, Rodrigo Arancibia ${ }^{\mathrm{a}}$, Juan Oyarzo ${ }^{\mathrm{a}}$, Gonzalo E. Buono-Core ${ }^{\mathrm{a}}$, A. Hugo Klahn ${ }^{a}{ }^{*}, 1$, Vania Artigas a' Mauricio Fuentealba ${ }^{a}$, Ramon Bosque ${ }^{b}$, Gabriel Aull] on ${ }^{b}$, (1) Concepción López ${ }^{\mathrm{b}, * *}, 1$, Mercè Font-Bardía ${ }^{\mathrm{c}}$, Teresa Calvet ${ }^{\mathrm{d}}$

* Corresponding author.

** Corresponding author.

E-mail addresses: hugo.klahn@pucv.cl (A.H. Klahn),

conchi.lopez@qi.ub.es (C. López).

1 Equal contribution. 
47 ABSTRACT:

48

49 The synthesis of novel cyrhetrenyl hydrazones of general formula $\left[\operatorname{Re}\{(\mathrm{h} 5-\mathrm{C} 5 \mathrm{H} 4) \mathrm{eC}(\mathrm{R} 1))^{1 / 4}\right.$

50 NNHR2\}(CO)3] \{with R1 1/4 H and R2 1/4 4-NO2eC6H4 (4a), C6H5 (4b) or H (4c) or R1 1/4 Me and R2

$51 \quad 1 / 44-\mathrm{NO} 2 \mathrm{eC} 6 \mathrm{H} 4(5 \mathrm{a}), \mathrm{C} 6 \mathrm{H} 5(5 \mathrm{~b})$ or $\mathrm{H}(5 \mathrm{c})\}$ is described. Compounds $4 \mathrm{ae} 4 \mathrm{c}$ and $5 \mathrm{ae} 5 \mathrm{c}$ were

52 characterized by mass spectrometry and IR spectroscopy. $1 \mathrm{H}$ and $13 \mathrm{C}\{1 \mathrm{H}\}$ NMR studies revealed that

$534 \mathrm{ae} 4 \mathrm{c}$ and $5 \mathrm{ae} 5 \mathrm{c}$ adopt the anti-(E) configuration in solution. X-ray crystal structures of compounds $4 \mathrm{a}$

54 and $5 \mathrm{c}$ confirmed the transarrangement of the cyrhetrenyl "Re(h5-C5H4)(CO)3" and the -NHR2

55 moieties and the existence of strong hydrogen bonds involving the eNHe unit. Molecular Orbital

56 calculations at a DFT level have also been carried out in order to rationalize the influence of the nature

57 of the substituent R3 of [R3CH 1/4 NNH(4-NO2eC6H4)] (R3 1/4 ferrocenyl, (3a), cyrhetrenyl (4a), phenyl

58 (6a) or cymantrenyl (7a) on the electronic delocalization, the nucleophilicity of the imine carbon, the

59 polarizability and hyperpolarizability of these compounds, and computational studies using time-

60 dependent density functional (TD-DFT) calculations have also been carried out in order to assign the

61 bands detected in their electronic spectra and to explain the effect produced by the solvent.

62

63

64

65 


\section{INTRODUCTION}

68 Sandwiches and three legged half-sandwich organometallic compounds have been studied since long 69 ago, but nowadays constitute a very attractive area of research [1e4]. Compounds of this kind with additional $\mathrm{eC}(\mathrm{R} 1)^{1 / 4} \mathrm{Ne}$ or $\mathrm{eC}(\mathrm{R} 1)^{1 / 4} \mathrm{NNHR} 2$ groups attached to the rings are specially relevant for different reasons. These include their utility as precursors in organic, inorganic and organometallic synthesis (especially as metallo-ligands to achieve polymetallic derivatives), their interesting (chemical, photochemical, electrochemical) properties as well as their applications in a variety of fields [1e4]. For instance, ferrocenylimines [5,6], oximes [7], azines and azoderivatives [8], thiosemicarbazones [9] or, to a lesser extent, monohydrazones [Fe(h5-C5H5) \{(h5-C5H4) eC(R1) 1/4 NeNHR2] (R1 1/4 H (1) or Me (2), Fig. 1) or the 1,10-dihydrazones (3) [10,11], are valuable as ligands in coordination and organometallic chemistry (i.e. to achieve cyclometallated compounds) [5,10]. Furthermore, mono- and disubstituted ferrocenyl hydrazones (1e3 in Fig. 1) with large non-linear optical (NLO) properties have also been reported [12].

80 On the other hand, the chemistry of cyrhetrene, [Re(h5-C5H5)(CO)3] (the typical example of a three legged half-sandwich rhenium complex), has undergone a rapid development in the last decade [13e15]. Functionalization of the ring or exchange of the $\mathrm{CO}$ groups by other mono or bidentate ligands have allowed to prepare a variety of new cyrhetrene derivatives. Most of them exhibit interesting properties, reactivity, (i.e. as metallo-ligands) and biological or catalytic activity [13e15]. Cyrhetrenylimines [6,14], amines [14a] and thiosemicarbazones [9a] have been described in the late years and their properties, applications and activities have been compared with those of their corresponding ferrocenyl analogues [6e9].

Despite the spectacular progress on the design and development of: a) organometallic compounds containing redox active centres $[1-4,5 \mathrm{a}, 5 \mathrm{~b}]$ and $\mathrm{b}$ ) new hydrazones as stimuli responsive molecules [16], cyrhetrenyl derivatives of the type $\left[\operatorname{Re}\left\{(\mathrm{h} 5-\mathrm{C} 5 \mathrm{H} 4) \mathrm{C}(\mathrm{R} 1)^{1 / 4} \mathrm{NNHR} 2\right\}(\mathrm{CO}) 3\right]$ are extremely scarce; as far as we know, that shown in Fig. 1, is the sole example [17]. Moreover, unsubstituted [Re\{(h5$\left.\mathrm{C} 5 \mathrm{H} 4) \mathrm{eC}(\mathrm{R} 1) \frac{1}{4} \mathrm{NNH} 2\right\}(\mathrm{CO}) 3$ ] compounds still remain unknown. In view of this and our interest to compare electronic effects of cyrhetrenyl and ferrocenyl moiety [5-7a,9a,10-11,14,15], here we present six new cyrhetrene derivatives of general formula $\left[\operatorname{Re}\left\{(\mathrm{h} 5-\mathrm{C} 5 \mathrm{H} 4) \mathrm{eC}(\mathrm{R} 1) \frac{1}{4} \mathrm{NNHR} 2\right\}(\mathrm{CO}) 3\right]$ with R1 1/4 $\mathrm{H}$ (4) orMe (5) and $\mathrm{R} 2 \frac{1}{4} 4$-NO2eC6H4 (a), C6H5 (b) or H(c). It should be noted that those with phenyl rings ( $4 \mathrm{ae} 4 \mathrm{~b}$ and $5 \mathrm{ae} 5 \mathrm{~b}$ ) could be visualized as derived from compounds 1 and 2, respectively (Fig. 1) by replacement of the "Fe(h5-C5H5)" unit by the "Re(CO)3" moiety. 


\section{RESULTS AND DISCUSSION}

\subsection{Synthesis and solution studies}

103 The new cyrhetrenyl hydrazones [ $\operatorname{Re}\{(\mathrm{h} 5-\mathrm{C} 5 \mathrm{H} 4)$ eC(R1) $1 / 4 \mathrm{NeNHR} 2\}(\mathrm{CO}) 3](4 \mathrm{a}, 4 \mathrm{~b}, 5 \mathrm{a}$ and 5b) were prepared by adaptation of the procedures reported for their ferrocenyl analogues ( 1 or 2 in Fig. 1) [12a]; while compounds $4 \mathrm{c}$ and $5 \mathrm{c}$ (with R2 $1 / 4 \mathrm{H}$ ) were obtained following the method described for 1,10diacetylferrocene dihydrazone [10c]. In all cases, the processes are based on condensation reactions between formyl- (for 4ae4c) or acetyl- (for 5ae5c) cyrhetrene and the corresponding hydrazine in anhydrous methanol (Scheme 1). The new compounds, that were isolated as yellow (4ae4c, 5a and 5c) or red (5b) crystalline solids after crystallization from $\mathrm{CH} 2 \mathrm{Cl} 2 /$ hexane mixtures, exhibit high solubility in $\mathrm{CH} 2 \mathrm{Cl} 2$ and $\mathrm{CHCl} 3$, and they are practically insoluble in hexane. It should be noted that $4 \mathrm{c}$ is less stable (in solution as well as in the solid state) than $4 \mathrm{a}, 4 \mathrm{~b}$ and $5 \mathrm{ae} 5 \mathrm{c}$ and itwas characterized

113 Compounds $4 \mathrm{ae} 4 \mathrm{c}$ and $5 \mathrm{ae} 5 \mathrm{c}$ were characterized by electron impact (EI) mass spectrometry, infrared spectroscopy and NMR studies. Their MS spectra showed peaks due to the molecular cations $[\mathrm{M}] \mathrm{p}$ and those arising from the successive dissociation of the remaining CO ligands. IR spectra of $4 a e 4 c$ and 5ae5c in $\mathrm{CH} 2 \mathrm{Cl} 2$ showed the following common features: a) two intense bands at 2023 and $1929 \mathrm{~cm} 1$, that are characteristic of the asymmetric (nas) and symmetric (ns) stretchings of the terminal CO ligands of cyrhetrene derivatives [9a,14,15], and b) an intense and sharp absorption (at around $1600 \mathrm{~cm}$ 1) in the same range as observed for ferrocenyl hydrazones [Fe(h5-C5H5) \{(h5-C5H4)eC(R1) 1/4 NeNHR2] with $\mathrm{R} 1 \frac{1}{4} \mathrm{H}$ (1) or $\mathrm{Me}(2)$ [10e12], that has been assigned to the stretching of the functional $\left.>\mathrm{C}\right] \mathrm{Ne}$. It is well-known that hydrazones may adopt two different forms (E- or Z-) $[6,18]$ in the solid state and also in solution. $1 \mathrm{H}$ and $13 \mathrm{C}\{1 \mathrm{H}\} \mathrm{NMR}$ spectra of $4 \mathrm{ae} 4 \mathrm{c}$ and $5 \mathrm{ae} 5 \mathrm{c}$ showed only one set of resonances, thus suggesting that only one of the two isomers was present in $\mathrm{CDCl} 3$ solution at room temperature (we will return to this point later on).

Proton-NMR spectra of $4 \mathrm{ae} 4 \mathrm{c}$ and $5 \mathrm{ae} 5 \mathrm{c}$ showed two triplets of identical intensities assigned to the pairs of protons $(\mathrm{H} 2, \mathrm{H} 5)$ and $(\mathrm{H} 3, \mathrm{H} 4)$ of the "Re(h5-C5H4)" moiety and an additional singlet, in the range $7.3<\mathrm{d}<8.0 \mathrm{ppm}$ for $4 \mathrm{ae} 4 \mathrm{c}$, or at around $1.9 \mathrm{ppm}$ (for $5 \mathrm{ae} 5 \mathrm{c}$ ), due to the $1 \mathrm{H}$ nuclei of the R1 units $(\mathrm{H}$ and $\mathrm{Me}$, respectively). The resonance of the eNHe proton appeared as a broad singlet for $4 \mathrm{c}$ and $5 \mathrm{c}$ (at 5.26 and $5.48 \mathrm{ppm}$ ); while for $4 \mathrm{a}, 4 \mathrm{~b}, 5 \mathrm{a}$ and $5 \mathrm{~b}$ this signal was much narrower and low-field shifted. Additional resonances due to the aromatic protons of the phenyl rings of $4 \mathrm{aeb}$ and $5 \mathrm{aeb}$ were also observed. 
follows the opposite trend [9a]. Thus suggesting that the nature of the organometallic framework modifies the degree of electronic delocalization on the "eC(R1) $1 / 4 \mathrm{NeNHe"} \mathrm{unit.}$

$13 \mathrm{C}\{1 \mathrm{H}\}$ NMR spectra of $4 \mathrm{ae} 4 \mathrm{c}$ and $5 \mathrm{ae} 5 \mathrm{c}$ exhibited the following common signals: a) two singlets in the low field area, of which that at d z 194 ppm, is due to the terminal CO ligands, and the other to imine carbon, and b) a set of three resonances, two of them in the range $81<\mathrm{d}<87 \mathrm{ppm}$ that correspond to the pairs $(\mathrm{C} 2, \mathrm{C} 5)$ and $(\mathrm{C} 3, \mathrm{C} 4)$ of the $\mathrm{C} 5 \mathrm{H} 4$ unit, while the third one that appeared at lower-fields and exhibited lower intensity, is attributed to the $\mathrm{C} 1$ carbon atom. For compounds $5 \mathrm{ae} 5 \mathrm{c}$ the resonance of the methylic protons occurred at higher fields and for $4 \mathrm{a}, 4 \mathrm{~b}, 5 \mathrm{a}$ and $5 \mathrm{~b}$ the group of resonances between 110 and $145 \mathrm{ppm}$ were assigned to the phenyl rings.

As mentioned in previous section with reference to the presence only one of two isomers, the $[1 \mathrm{He} 1 \mathrm{H}]-$ NOESY experiments were performed in $\mathrm{CDCl} 3$ at $298 \mathrm{~K}$. In the spectra of 4a and 5a (Figs. S1 and S2) moderate cross-peaks were observed between the amine-NH region (d 7.98 for $4 \mathrm{a}, \mathrm{d} 7.66$ for $5 \mathrm{a})$ and the resonances the protons of the R1 unit (d 7.45 for $4 a, d 2.02$ for $5 a$ ). This is only possible if the cyrhetrenyl and the eNHR2 groups are in a transarrangement (E-form). Since NMR studies revealed that compounds $4 \mathrm{~b}, 4 \mathrm{c}, 5 \mathrm{~b}$ and $5 \mathrm{c}$ showed a similar behaviour in solution, we assumed that they also adopted the $\mathrm{E}$ form. Compounds $4 \mathrm{a}$ and $5 \mathrm{c}$ were also characterized by $\mathrm{X}$-ray diffraction.

\subsection{Description of the crystal structures of compounds $4 \mathrm{a}$ and $5 \mathrm{c}$}

These structures consist on discrete molecules of [Re $\left.\left\{(\mathrm{h} 5-\mathrm{C} 5 \mathrm{H} 4) \mathrm{eC}(\mathrm{R} 1)^{1 / 4} \mathrm{NeNH}(\mathrm{R} 2)\right\}(\mathrm{CO}) 3\right]$ with $\mathrm{R} 1 \frac{1}{4} \mathrm{H}$ and R2 $1 / 4$ 4-NO2eC6H4 (in 4a) or R1 1/4 Me and R2 $1 / 4 \mathrm{H}$ (in 5c) $\}$ with the typical three-ledged piano-stool structure (Figs. 2 and 3, respectively). In the two cases bond lengths and angles of the cyrhetrenyl array as well as the distance Re $\$ \$$ centroid of the "C5H4" ring \{hereinafter referred to as $\mathrm{Cg}(1)\}$ (Table 1) are similar to those reported for related [Re $\{(\mathrm{h} 5-\mathrm{C} 5 \mathrm{H} 4 \mathrm{R} 3\}(\mathrm{CO}) 3]$ derivatives $[14,15,19]$. As shown in Figs. 2 and 3, the -NHR2 moiety and the (h5-C5H4) unit are in a trans-

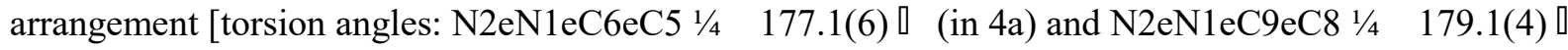
(in 5c)], thus confirming that they also adopt the $\mathrm{E}$ form in the solid state. In $4 \mathrm{a}$, the $\mathrm{N} 1 \mathrm{eN} 2$ bond distance $[1.368(6) \AA]$ is very similar to that reported for $\mathrm{R} 3 \mathrm{CH} 1 / 4$ $\mathrm{NeNH}(4 \mathrm{eNO} 2 \mathrm{eC6H4})$ with R3 1/4 Ph (6a) [20] [1.361(7) $\AA$ ], but in 4a the C6eN1 bond length [1.261(7) $\AA]$ is shorter than in $6 \mathrm{a}[1.286(7) \AA]$, thus suggesting that in $4 \mathrm{a}$ the $>\mathrm{C}] \mathrm{Ne}$ bond is stronger than in $6 \mathrm{a}$. Furthermore, the planes defined by the $\mathrm{C} 5 \mathrm{H} 4$ (in 4a) ring and the "C5, C6 and N1" form an angle of 4.7[ (in 4a); while in 6a the phenyl and the CipsoeC]Ne atoms are less coplanar [interplanar angle $1 / 4$ $7.8 \square$ (in 6a)]. It is well known that for hydrazones R1CH $1 / 4$ N-NHR2 large angles between main planes of aromatic (or heteroaromatic) groups of the R1 and R2 substituents are usually accompanied with large hyperpolarizabilities, which is relevant in view of their potential non-linear optical properties [16,21]. In $\mathrm{PhCH} 1 / 4 \mathrm{NeNH}(4-\mathrm{NO} 2 \mathrm{eC} 6 \mathrm{H} 4)$ (6a) this angle (12.5ロ ) is slightly greater than in 4a (11.0[) and, thus the cyrhetrenyl array is expected to produce a decrease in the hyperpolarizability in relation to that of 6a. In compound [ $\operatorname{Re}\{(\mathrm{h} 5-\mathrm{C} 5 \mathrm{H} 4)$ eC(Me) $1 / 4 \mathrm{NeNH} 2\}(\mathrm{CO}) 3](5 \mathrm{c})$ : a) the N1eN2 bond length is 
practically identical to that of $4 \mathrm{a}, \mathrm{b}$ ) the two bonds of the "Cipso- $\mathrm{C}=\mathrm{N}$ " unit are a bit larger than in $4 \mathrm{a}$ and, c) the imine unit is less co-planar with the $\mathrm{C} 5 \mathrm{H} 4$ ring than in $4 \mathrm{a}$ [interplanar angles being: 17.9] (in 5c) versus 4.7[ (in 4a)]. These findings, that are similar to those found in the ferrocenylimines [Fe(h5-C5H5)\{(h5-C5H4)eC(R4) 1/4 N(C6H5)] $\{\mathrm{R} 4$ 1/4 Me or H $\}$ [22], suggest that in 4a the electronic communication between the -NHR2 unit and the cyrhetrenyl array is greater than in 5c (we will return to this point later on). The assembly of the molecules of $4 \mathrm{a}$ and $5 \mathrm{c}$ in the crystals are markedly different. Figs. S3 and S4 (Supplementary Materials) contain schematic views of the connectivity showing the main intermolecular contacts.

2.3. The study of the influence of the $\mathrm{R} 3$ substituent of $\mathrm{R} 3 \mathrm{CH} 1 / 4 \mathrm{NeNH}(4-\mathrm{NO} 2 \mathrm{C} 6 \mathrm{H} 4)$ and the solvent on their electronic spectra In a first attempt to elucidate the effect produced by the substituent $\mathrm{R} 3$ on the properties of the hydrazones we decided to perform a comparative study of the ultravioletevisible spectra of compounds R3CH 1/4 NeNH(4-NO2C6H4) with R3 1/4 ferrocenyl (3a), cyrhetrenyl (4a) and phenyl (6a). Absorption band in the range $380 \mathrm{e} 400 \mathrm{~nm}$. Comparison of data reveals that the replacement of the ferrocenyl unit (in 3a) by the cythenetryl (in 4a) or the phenyl (in 6a) produces a shift of the band to lower wavelengths. The UVevis spectra of these products in the polar solvents acetone and acetonitrile were practically identical to those obtained in $\mathrm{CHCl} 3$ except for a tiny shift of the band (ca. 5e10 nm) (Table 2 and Figs S5eS7). Computational studies (see below) have allowed us to explain these experimental findings and the origin of this transition. It should be noted that the additional and weaker band observed in the UVevis. Spectra of 3a in $\mathrm{CHCl} 3$, acetone or acetonitrile that appears as a shoulder at around 495 nm(Fig. 4 and Fig. S5), is typical of most ferrocene derivatives.

\subsection{Computational studies on the influence of the $\mathrm{R} 3$ substituent of $\mathrm{R} 3 \mathrm{CH} 1 / 4 \mathrm{NeNH}(4-\mathrm{NO} 2 \mathrm{C} 6 \mathrm{H} 4)$ on} the properties of the compounds

It is well-known that hydrazones are valuable reagents in synthetic chemistry. In this field most of the reactions involve the imine carbon and its nucleophilicity $[16,18]$. In view of this and in order to compare the effect produced by the substituents R3 (ferrocenyl, cyrhetrenyl or phenyl) of R3CH $1 / 4$ $\mathrm{NeNH}(4-\mathrm{NO} 2 \mathrm{C} 6 \mathrm{H} 4)$ on: a) the nucleophilicity of the imine carbon, b) the electronic delocalization between the R3 substituent and the 4-nitrophenyl ring and, c) the properties of these compounds, we also undertook DFT calculations of hydrazones 3a, 4a and 6a. For comparison purposes the cymantrene derivative (7a) with $\mathrm{R} 3$ 1/4 Mn(h5-C5H4)(CO)3 was also included.

All the calculations were carried out using the B3LYP hybrid functional [24] and the LANL2DZ basis set [25] implemented in the Gaussian09 program [26]. Geometries of compounds 3a, 4ae7a were optimised without imposing any restriction. Final atomic coordinates for the optimized geometries are included as supplementary information, (Tables S1eS4). Bond lengths and angles of the optimised 
geometry of 4a and 6a were consistent with those obtained from the X-ray studies (the differences did not clearly exceed 3s) and those of 3a fall in the range reported for related ferrocenyl Schiff bases [19]. Afterwards, molecular orbital (MO) calculations of the optimized geometries were carried out. Comparison of the calculated HOMO - LUMO energy gaps (DE 1/4 ELUMO EHOMO) (Table S5) reveals that DE increases as follows: $3 a<6 a<4 a \square 7 a$. Thus showing that the ferrocenyl (in $3 a$ ) or the "M(h5-C5H4)(CO)3" unit (in 4a and 7a)\} produce opposite effects on the energy gap when compared the phenyl derivative (6a).

As shown in Fig. 5 for the four compounds HOMO (and also LUMO) are similar; however, a careful analysis of their compositions reveal significant variations in the contributions of the main fragments [R3, eCH]NeNHe and the 4-nitrophenyl group (Table S5]. For 4a, 6a and 7a, the contributions of the 4nitrophenyl group and the R3 substituent are very similar, but in 6a the hydrazone has a greater contribution than in $4 \mathrm{a}$ and $7 \mathrm{a}$. For $3 \mathrm{a}$, the relative weight of the nitrophenyl (18\%) groups is significantly smaller than in $4 a, 7 a$ and $6 a$, and the participation of ferrocenyl group reaches the $47 \%$. A parallel situation arises from the comparison of the LUMO orbitals, for 3a the contribution of the 4$\mathrm{NO} 2 \mathrm{eC} 6 \mathrm{H} 4(82 \%)$ is higher than in $4 \mathrm{a}, 6 \mathrm{a}$ and $7 \mathrm{a}$ (Table S5). Comparative analyses of the charge distribution on the 4-nitrophenyl group, shows that the ferrocene derivative (3a) concentrates electron density (that is, larger negative charge) in the eNO2 group (Table S6), but it decreases for $4 \mathrm{a}, 6 \mathrm{a}$ and $7 \mathrm{a}$ derivatives. In addition, the charge of the imine carbon increases according to the trend $4 a \square 6 a \square 7 a<3 a$. This finding indicates the replacement of the cyrhetrenyl, cymantrenyl or phenyl groups by a ferrocenyl unit produces a significant change in the nucleophilicity of this carbon which is relevant in view of their reactivity and potential utility in synthesis $[16,18]$. As mentioned above, it is well-known that hydrazones are also attractive to achieve non linear optic (NLO) systems $[12,16,18,21]$. In these cases, the analysis of the effect of an external electric field on the permanent dipole moment is a valuable tool to understand their potential NLO properties. When small modification of the dipole moment is expected, a linear model considering the polarizability is used, which is equivalent to apply the harmonic approximation. Since the nature of the NLO response follows from the periodic vibration, we have also calculated static $\left(\mathrm{u}^{1 / 4} 0\right)$ and frequency-dependent $\left(\mathrm{u}^{1 / 4} 0.1\right)$ vacuum polarizabilities of the four hydrazones. The results (Table S7), reveal that isotropic polarizabilities increase according to the sequence $6 a<3 a<7 a<4 a$.

On the other hand, the inclusion of an anharmonic correction related to the second order term allows the determination of the hyperpolarizability, a third order tensor divided into tensorial components. A strong hyperpolarizability results in a large second order NLO response. According to our calculations (Table S8), hyperpolarizabilities are higher in the plane containing the aromatic rings. This fact can be adscribed to the easier flow of electrons along the $\mathrm{p}$ system. Also, changes in the substituent R3 result in significant variations of the hyperpolarizability. In particular, for compounds $3 a$, $4 a$ and $7 a$, where the imine carbon is attached to the $\mathrm{C} 5 \mathrm{H} 4$ ring, the first hyperpolarizability follows the trend $6 \mathrm{a}<7 \mathrm{a} \ll 3 \mathrm{a}$. This is consistent with the differences in the relative orientation of the rings (Table S9). The non- 
247 planarity of the aromatic system results in a breakage of the p system that lowers the hyperpolarizability.

248 On these basis, compound 3a, appears to be the best candidate for a large NLO response.

249 On the other hand and in order to elucidate the origin of the intense band detected in the UVevis spectra

250 of compounds $3 \mathrm{a}, 4 \mathrm{a}$ and $6 \mathrm{a}$ in the range $380 \mathrm{nme} 410 \mathrm{~nm}$, we decided to undertake a study based on the

251 time-dependent DFT (TD-DFT) methodology [27] to achieve the assignment of the bands detected in

252 the UVevis. spectra of hydrazones $3 \mathrm{a}, 4 \mathrm{a}$ and $6 \mathrm{a}$. For comparison purposes, we also included compound

253 7a. After the optimization of the geometries (see above), the excitation energies and the corresponding

254 oscillator strengths were calculated.

255 The results obtained from calculations in gas phase, $\mathrm{CHCl} 3$ and acetone reveal that the absorption band

256 at around $400 \mathrm{~nm}$ arises from a combination of several transitions, of which those with greater

257 contribution are presented in Table 3. For compounds $4 \mathrm{a}$ and 6a, the main contribution arises from

258 HOMO / LUMO transition (Table 3 and Fig. 5); but for 3a and 7a, the observed band results from the

259 combination of several transitions. One of them is the HOMO/LUMO, but now its relative weight is

260 clearly smaller than for $4 \mathrm{a}$ and $6 \mathrm{a}$. Additional transitions occurring in the same energy range, but with

261 smaller contributions than are presented in Table 3. These studies also revealed that when $\mathrm{CHCl} 3$ is

262 replaced by acetone the band shifts to higher wavelengths (Fig. S8 Table S10) in good agreement with

263 the experimental results (Table 2). The computational analysis of the results obtained for 3a also

264 confirmed the existence of a d-d transition of the Fe (II) centre at ca. 495e500 nmthat agrees with the

265 shoulder observed in the UVevis. spectra of compound 3a (Fig. 4 and Fig. S5). 


\section{CONCLUSIONS}

268

269 We have prepared and characterized six novel cyrhetrenyl hydrazones $\left[\operatorname{Re}\left\{(\mathrm{h} 5-\mathrm{C} 5 \mathrm{H} 4) \mathrm{eC}(\mathrm{R} 1) \frac{1}{4}\right.\right.$

270 NNHR2 $\}(\mathrm{CO}) 3]\{\mathrm{R} 1$ 1/4 H (4) orMe (5) and R2 1/4 4-NO2eC6H4 (a), C6H5 (b) or H (c) $\}$. NMR studies

271 and the crystal structures of $4 \mathrm{a}$ and $5 \mathrm{c}$ confirm that the organometallic framework and the amine

272 nitrogen are in a trans-arrangement (Eform). It should be noted that $\operatorname{Re}(\mathrm{I})$ compounds similar to those

273 presented here were not known before, except for [ $\mathrm{Re}\{(\mathrm{h} 5-\mathrm{C} 5 \mathrm{H} 4) \mathrm{eCH}] \mathrm{NNH}[(2,4-$

$274 \mathrm{NO} 2) 2 \mathrm{C} 6 \mathrm{H} 3]\}(\mathrm{CO}) 3$ ] (Fig. 1) that was described in 1981. Moreover, the comparison of the results

275 obtained from theoretical studies undertaken for hydrazones [R3CH 1/4 NNH(4-NO2eC6H4)] \{with R3

$2761 / 4$ ferrocenyl (3a), cyrhetrenyl (4a), cymantrenyl (7a) or phenyl (6a) $\}$ have allowed us to explain the

277 effect produced by the R3 groups on: a) the HOMO and LUMO orbitals and the energy gap, b) the

278 charge distribution and the nucleophilicity of the imine carbon, and c) their polarizabilities and

279 hiperpolarizabilities.

280 Computational studies undertaken using TD-DFT methodology reveal a reasonable agreement between the experimental and calculated UVevis. spectra and have allowed the assignment of the main absorptions and to explain the effect produced by the substituent R3 on their absorption spectra in two different solvents ( $\mathrm{CHCl} 3$ and acetone).

284

285

286 


\subsection{Experimental details}

291 Reactions were performed under a nitrogen atmosphere using standard Schlenk techniques. 4-

292 Nitrophenylhydrazine (98\%), phenylhydrazine (98\%) and hydrazine monohydrate (65\%) were obtained from Aldrich and used as received, and compounds [Re(h5-C5H4C(O)R1)(CO)3] (R1 1/4 H or Me) were prepared as described before $[14 \mathrm{~b}, \mathrm{c}]$. Solvents $(\mathrm{CH} 2 \mathrm{Cl} 2, \mathrm{MeOH}, \mathrm{EtOH}$ and hexane) were obtained from

295 commercial sources and purified following standard methods [28]. Electron impact (EI) mass spectrawere obtained on a Shimadzu GC-MS spectrometer $(70 \mathrm{eV})$ at the Laboratorio de Servicios Analíticos, (Pontificia Universidad Cat $\llbracket$ olica de Valparaíso). Infrared spectra were recorded in $\mathrm{CH} 2 \mathrm{Cl} 2$ solution using $\mathrm{NaCl}$ cells and a PerkineElmer - 1605 FT-IR spectrophotometer. Ultravioletevisible spectra of compounds 3a, 4a and 6a in $\mathrm{CHCl} 3$ (99.4\%); acetone (99.5\%) or acetonitrile (99.9\%) were recordered at $298 \mathrm{~K}$ with a SHIMADZU UV-1800 spectrophotometer. $1 \mathrm{H}$ and $13 \mathrm{C}\{1 \mathrm{H}\}$ NMR spectra were registered at $298 \mathrm{~K}$ on a Bruker AVANCE 400 III and Bruker Fourier 300 spectrometers using $\mathrm{CDCl} 3$ as a solvent. The chemical shifts are referenced to the residual deuterated solvent peaks. Chemical shifts (d) are given in ppm, and the coupling constants (J) in Hz. In the characterization section of compounds 4aec and 5aec the assignment of NMR data correspond to the labelling pattern presented in Scheme 1. [Abbreviations for the multiplicities of the signals detected in 1H NMR: $\mathrm{s}$ (singlet), d (doublet), t (triplet), m (multiplet) and br.s (broad singlet)].

\subsection{Synthesis of the compounds}

[Re $\left\{(\mathrm{h} 5-\mathrm{C} 5 \mathrm{H} 4) \mathrm{eC}(\mathrm{R} 1)^{1 / 4} \mathrm{NeNH}(4-\mathrm{NO} 2 \mathrm{eC} 6 \mathrm{H} 4)\right\}(\mathrm{CO}) 3$ ] with R1 1/4 H (4a) or Me (5a). Hydrazones 4a and $5 \mathrm{a}$ were prepared as described for the analogous ferrocenyl hydrazones [12a], except for the following experimental conditions: a) the reactions were performed under $\mathrm{N} 2$ atmosphere, b) the corresponding $\left[\operatorname{Re}\{(\mathrm{h} 5-\mathrm{C} 5 \mathrm{H} 4 \mathrm{C}(\mathrm{O}) \mathrm{R} 1\}(\mathrm{CO}) 3]\right.$ derivative [125 mg, $0.34 \mathrm{mmol}$ (for $\mathrm{R} 1 \frac{1}{4} \mathrm{H}$ ) or $163 \mathrm{mg}$, $0.43 \mathrm{mmol}$ (for R1 1/4 Me)] was treated with the stoichiometric amount of 4-nitrophenylhydrazine and anhydrous ethanol $(8 \mathrm{~mL})$ was used as solvent, $\mathrm{c})$ the reaction mixture was stirred for $2 \mathrm{~h}$ in the presence of molecular sieves and d) the solid formed after this period was collected by filtration, washed with three portions of $5 \mathrm{~mL}$ of cold ethanol and the solvent was removed in a rotary evaporator. Compounds 4a and 5a were isolated as yellow solids. Yields: 62\% (105 mg, $0.21 \mathrm{mmol})$ for 4a and 75\% (165 mg, $0.32 \mathrm{mmol}$ ) for 5a.Characterization data for 4a:MS (based on 187Re) m/z: 499 [M]p; 471 [M CO]p; $443[\mathrm{M} \quad 2 \mathrm{CO}] \mathrm{p}$ and 415 [M 3CO]p; IR data (CH2Cl2, cm 1): 2025 (s) n(CO); 1930 (vs), n(CO) and $1598(\mathrm{w}), \mathrm{n}(>\mathrm{C}] \mathrm{Ne})$. 1H NMR data (400 MHz, CDCl3): d 5.40 (t, 2H, 3JH,H 1/4 2.3, H3 and H4); $5.82(\mathrm{t}, 2 \mathrm{H}, 3 \mathrm{JH}, \mathrm{H}$ 1/4 2.3, $\mathrm{H} 2$ and $\mathrm{H} 5) ; 7.04(\mathrm{~d}, 2 \mathrm{H}, 3 \mathrm{JH}, \mathrm{H} 1 / 4$ 8.2, 2Hb); $7.45(\mathrm{~s}, 1 \mathrm{H}, \mathrm{eCH}] \mathrm{Ne}) ; 7.98$ (s, $1 \mathrm{H}, \mathrm{eNHe})$ and 8.17 (d, 2H, 3JH,H 1/4 8.2, 2Ha). 13C $\{1 \mathrm{H}\}$ NMR data (CDCl3): $\mathrm{d} 84.9$ (C2 and C5); 85.6 (C3 and C4); $102.1(\mathrm{C} 1) ; 113.2(\mathrm{Ca}) ; 127.4(\mathrm{Cb}) ; 134.1(\mathrm{Cg}) ; 150.0(>\mathrm{C}] \mathrm{Ne}), 194.4(\mathrm{CO})$ the 
resonance due to the quaternary Cipso carbon was not observed. For 5a: MS (based on 187Re) m/ z: 513 $[\mathrm{M}] \mathrm{p} ; 485[\mathrm{M} \quad \mathrm{CO}] \mathrm{p} ; 457[\mathrm{M} \quad 2 \mathrm{CO}] \mathrm{p}$ and $429[\mathrm{M} \quad 3 \mathrm{CO}] \mathrm{p}$; IR data $(\mathrm{CH} 2 \mathrm{Cl} 2, \mathrm{~cm} \quad$ 1): 2024 (s), $\mathrm{n}(\mathrm{CO}) ; 1929(\mathrm{vs}), \mathrm{n}(\mathrm{CO})$ and $1601(\mathrm{w}), \mathrm{n}(>\mathrm{C}] \mathrm{Ne}) .1 \mathrm{H}$ NMR data (300 MHz, CDCl3): d 2.02 (s, 3H, $\mathrm{Me}) ; 5.39$ (t, 2H, 3JH,H 1/4 2.3, $\mathrm{H} 3$ and $\mathrm{H} 4) ; 5.82$ (t, 2H, 3JH,H 1/4 2.3, H2 and H5); 7.10 (d, 2H, 3JH,H $1 / 48.2,2 \mathrm{Hb}) ; 7.66(\mathrm{~s}, 1 \mathrm{H}, \mathrm{eNHe})$ and $8.18(\mathrm{~d}, 2 \mathrm{H}, 3 \mathrm{JH}, \mathrm{H} 1 / 48.2,2 \mathrm{Ha}) .13 \mathrm{C}\{1 \mathrm{H}\}$ NMR data (CDCl3): $\mathrm{d}$ $31.6(\mathrm{Me}) ; 82.9$ (C2 and C5); $84.4(\mathrm{C} 3$ and C4); $104.4(\mathrm{C} 1) ; 112.3(\mathrm{Ca}) ; 126.1(\mathrm{Cb}) ; 138.7(\mathrm{Cg}) ; 140.9$ (Cipso); $149.1(>\mathrm{C}] \mathrm{Ne})$ and $193.4(\mathrm{CO})$.

$[\operatorname{Re}\{(\mathrm{h} 5-\mathrm{C} 5 \mathrm{H} 4) \mathrm{eC}(\mathrm{R} 1) 1 / 4 \mathrm{NeNH}(\mathrm{C} 6 \mathrm{H} 5)\}(\mathrm{CO}) 3]$ with $\mathrm{R} 1 \frac{1}{4} \mathrm{H}$ (4b) or Me (5b). The synthesis of these products was carried out following the same procedure as described above for $4 \mathrm{a}$ and $5 \mathrm{a},[\operatorname{Re}\{(\mathrm{h} 5-$ $\mathrm{C} 5 \mathrm{H} 4 \mathrm{C}(\mathrm{O}) \mathrm{R} 1\}(\mathrm{CO}) 3$ ] derivative [100 mg, $0.275 \mathrm{mmol}$ (for R1 1/4 H) or $100 \mathrm{mg}, 0.28 \mathrm{mmol}$ (for R1 1/4 $\mathrm{Me})$ ], but replacing the 4- nitrophenylhydrazine by the stoichiometric amount of phenylhydrazine [27.2 $\mathrm{mL},(0.275 \mathrm{mmol})$ and $27.7 \mathrm{~mL},(0.28 \mathrm{mmol})$ for $4 \mathrm{~b}$ and $5 \mathrm{~b}$, respectively]. After work-up, the desired compounds were isolated as yellow (4b) and red (5b) solids. These products were afterwards recrystallized in a $\mathrm{CH} 2 \mathrm{Cl} 2 /$ hexane $(1: 5)$ mixture at $18 \square \mathrm{C}$. Yields: $78 \%$ (95 mg, $0.21 \mathrm{mmol})$ for $4 \mathrm{~b}$, and $86 \%$ (110 mg, $0.24 \mathrm{mmol}$ ) for $5 \mathrm{~b}$. Characterization data for $4 \mathrm{~b}$ : MS (based on 187Re) m/z: 454 $[\mathrm{M}] \mathrm{p} ; 426[\mathrm{M} \quad \mathrm{CO}] \mathrm{p} ; 398[\mathrm{M} \quad 2 \mathrm{CO}] \mathrm{p}$ and $370[\mathrm{M} \quad 3 \mathrm{CO}] \mathrm{p}$; IR data $(\mathrm{CH} 2 \mathrm{Cl} 2, \mathrm{~cm} \quad$ 1): 2024 (s), $\mathrm{n}(\mathrm{CO}) ; 1929$ (vs), $\mathrm{n}(\mathrm{CO})$ and 1599 (w), n(>C JNe). 1H NMR data (400 MHz, CDCl3): d 5.34 (t, 2H, $3 \mathrm{JH}, \mathrm{H} 1 / 42.3, \mathrm{H} 3$ and $\mathrm{H} 4) ; 5.75(\mathrm{t}, 2 \mathrm{H}, 3 \mathrm{JH}, \mathrm{H} 1 / 42.3, \mathrm{H} 2$ and $\mathrm{H} 5) ; 6.84(\mathrm{~m}, 3 \mathrm{H}, 2 \mathrm{Hb}$ and $\mathrm{Hg}) ; 7.02(\mathrm{~m}$, $2 \mathrm{H}, 2 \mathrm{Ha}) ; 7.37(\mathrm{~s}, 1 \mathrm{H}, \mathrm{eCH}] \mathrm{Ne})$ and $7.56(\mathrm{~s}, 1 \mathrm{H}, \mathrm{eNHe}) .13 \mathrm{C}\{1 \mathrm{H}\} \mathrm{NMR}$ data $(\mathrm{CDCl} 3): \mathrm{d} 82.5(\mathrm{C} 2$ and C5); 83.9 (C3 and C4); $102.4(\mathrm{C} 1) ; 112.9(\mathrm{Ca}) ; 120.7$ (Cg); 128.2 (Cipso); $129.3(\mathrm{Cb}) ; 143.9(\mathrm{eCH}] \mathrm{Ne})$ and 193.7 (CO). For 5b: MS (based on 187Re) m/z: $468[\mathrm{M}] \mathrm{p} ; 440[\mathrm{M} \quad \mathrm{CO}] \mathrm{p} ; 412[\mathrm{M} \quad 2 \mathrm{CO}] \mathrm{p}$ and 384 [M 3CO]p; IR data (CH2Cl2, cm 1): 2022 (s), n(CO); 1924 (vs), n(CO) and 1597 (w), $\mathrm{n}(>\mathrm{C}] \mathrm{Ne})$. 1H NMR data (400 MHz, CDCl3): d 1.97 (s, 3H, Me); 5.35 (t, 2H, 3JH,H 1/4 2.3, H3 and H4); 5.75 (t, 2H, 3JH,H 1/4 2.3, H2 and H5); 6.87 (m, 3H, 2Hb and $\mathrm{Hg}) ; 7.09$ (m, 2H, 2Ha); and $7.25(\mathrm{~s}, 1 \mathrm{H}$, eNHe). 13C $\{1 \mathrm{H}\}$ NMR data (CDCl3): d 30.1 (Me); 81.9 (C2 and C5); 84.0 (C3 and C4); $101.8(\mathrm{C} 1)$; $113.4(\mathrm{Ca}) ; 120.5(\mathrm{Cg}) ; 129.4(\mathrm{Cb}) ; 144.5(>\mathrm{C}] \mathrm{Ne})$ and $194.0(\mathrm{CO})$; the resonance due to the quaternary Cipso carbon was not observed.

$\left[\operatorname{Re}\left\{(\mathrm{h} 5-\mathrm{C} 5 \mathrm{H} 4) \mathrm{CC}(\mathrm{R} 1)^{1 / 4} \mathrm{NeNH} 2\right\}(\mathrm{CO}) 3\right]$ with R1 1/4 H (4c) or Me (5c). The corresponding [Re(h5$\mathrm{C} 5 \mathrm{H} 4 \mathrm{C}(\mathrm{O}) \mathrm{R} 1)(\mathrm{CO}) 3$ ] compound \{with R1 1/4 H (100 mg, $0.27 \mathrm{mmol}$ ) (for 4c) or Me (100 mg; 0.26 $\mathrm{mmol}$ ) (for $5 \mathrm{c})\}$ was dissolved in anhydrous methanol $(12 \mathrm{~mL})$ and treated with an excess of hydrazine monohydrate $(140 \mathrm{~mL}, 2.7 \mathrm{mmol}$ ). The reaction mixture was stirred under $\mathrm{N} 2$ atmosphere for $2 \mathrm{~h}$ (for $4 \mathrm{c}$ ) or $18 \mathrm{~h}$ (for $5 \mathrm{c}$ ). Then, the solvent was evaporated to dryness under vacuum. The residue was dissolved in $10 \mathrm{~mL}$ of $\mathrm{CH} 2 \mathrm{Cl} 2$, transferred to an extraction funnel, and treated with $30 \mathrm{~mL}$ of water to remove the excess of hydrazine. Finally, the organic extract was collected, dried over Na2SO4 and solution was concentrated to dryness on a rotary evaporator giving yellow solids. They were later on recrystallized in $\mathrm{CH} 2 \mathrm{Cl} 2 /$ hexane mixtures [(1:5) (for 4c) or (1:3) (for 5c)] at 18 C. (Yields: 69\% (70 $\mathrm{mg}, 0.19 \mathrm{mmol})$ for $4 \mathrm{c}$ and $69 \%$ (70 $\mathrm{mg}, 0.18 \mathrm{mmol})$ for $5 \mathrm{c}$. Characterization data for $4 \mathrm{c}$ : MS (based on 
187Re) m/z: $378[\mathrm{M}] \mathrm{p} ; 350[\mathrm{M} \quad \mathrm{CO}] \mathrm{p} ; 322[\mathrm{M} \quad$ 2CO]p and $294[\mathrm{M} \quad 3 \mathrm{CO}] \mathrm{p}$; IR data $(\mathrm{CH} 2 \mathrm{Cl}$, cm 1): 2024 (s), n(CO); 1920 (vs), n(CO); 1603 (w), n(>C]Ne). 1H NMR data (400 MHz, CDCl3): d 5.31 (t, 2H, 3JH,H 1/4 2.3, H3 and H4); 5.48 (br.s, 2H, NH2); 5.66 (t, 2H, 3JH,H 1/4 2.3, H2 and H5); 7.34 (s, 1H, eCH]Ne). 13C $\{1 \mathrm{H}\}$ NMR data (CDCl3): d 84.8 (C2 and C5); 86.4 (C32 and C4); 95.8 (C1); $154.8(\mathrm{eCH}] \mathrm{Ne}$ ) and $192.5(\mathrm{CO})$. For 5c: MS (based on 187Re) m/z: $392[\mathrm{M}] \mathrm{p} ; 364$ [M CO]p; $336[\mathrm{M}$ 2CO]p; 308 [M 3CO] p; IR data (CH2Cl2, cm 1): 2021 (s), n(CO); 1925 (vs), n(CO) and 1608 (w), n(>C]Ne). 1H NMR data (400 MHz, CDCl3): d 1.86 (s, 3H, Me); 5.26 (br.s, 2H, NH2); 5.32 (t, 2H, $3 \mathrm{JH}, \mathrm{H} 1 / 42.3, \mathrm{H} 3$ and $\mathrm{H} 4) ; 5.66$ (t, 2H, 3JH,H 1/4 2.3, $\mathrm{H} 2$ and $\mathrm{H} 5) .13 \mathrm{C}\{1 \mathrm{H}\}$ NMR data (CDCl3): $\mathrm{d} 12.2$ (Me); 81.9 (C2 and C5); 84.0 (C3 and C4); 106.8 (C1); $139.7(>\mathrm{C}] \mathrm{Ne})$ and $193.9(\mathrm{CO})$.

\subsection{Crystal structure determinations}

A prismatic crystal of $4 \mathrm{a}$ or 5c (sizes in Table 4)was selected. The former was mounted on a MAR345 diffractometer with an image plate detector. Unit-cell parameters (Table 4) were determined from 255 reflections $(3[<\mathrm{q}<31])$ and refined by least-squares method. Intensities were collected with graphite monochromatized Mo Ka radiation. For 4a, 11801 reflections were measured in the range $1.78 \square$ q $\quad 30.30 \square$, of which 3765 were nonequivalent by symmetry $\{$ Rint (on I) $1 / 40.0488\}$ and 3192 reflections were assumed as observed applying the condition I $>2 \mathrm{~s}(\mathrm{I})$. Lorentz-polarization and absorption corrections were made. The structure was solved by Direct methods, using SHELXS computer program [29] and refined by fullmatrix least-squares method with SHELX97 computer program [30] using 11801 reflections, (very negative intensities were not assumed). The function minimized was $\mathrm{S} w|| \mathrm{Fo}|2-| \mathrm{Fc}|2| 2$, where $\mathrm{w} 1 / 4$ [s2(I) $\mathrm{p}(0.0556 \mathrm{P}) 2 \mathrm{p} 0.5148 \mathrm{P}] \quad 1$, and $\mathrm{P} 1 / 4(|\mathrm{Fo}| 2 \mathrm{p} 2|\mathrm{Fc}| 2) / 3$, f, f0 and f00 were taken from International Tables of X-Ray Crystallography [31]. All $\mathrm{H}$ atoms were computed and refined, using a riding model, with an isotropic temperature factor equal to 1.2 times the equivalent temperature factor of the atom linked. The crystal of $5 \mathrm{c}$ was mounted on top of glass fibres in a random orientation. Diffraction data were collected at 296.15 K on a Bruker D8 QUEST diffractometer equipped with a bidimensional CMOS Photon100 detector, using graphite monochromated Mo-Ka radiation. The diffraction frames were integrated using the APEX2 package [32] and were corrected for absorptions with SADABS. Using OLEX2 as graphical interface, the structure was solved with OLEX2 structure solution program [33] by charge flipping and refined with the Gauss-Newton refinement package. In this case, non-hydrogen atoms were refined with anisotropic displacement parameters and $\mathrm{H}$ atoms were finally included in their calculated positions.

394 The final $\mathrm{R}$ (on F) factorwas 0.036 for 4a, and 0.015 for 5c; wR(on $|\mathrm{F}| 2$ ) $1 / 40.098$ (4a) [or 0.044 (5c)], and the goodness of fit $1 / 41.141$ and 1.396 (for $4 \mathrm{a}$ and 5c, respectively). The number of refined parameters and further details concerning the resolution and refinement of the crystal structures of $4 \mathrm{a}$ and $5 \mathrm{c}$ are presented in Table 4. 
399 Calculations were carried out using the Gaussian09 package [26]. The hybrid density function method 400 known as B3LYP was applied [24]. Effective core potentials (ECP) were used to represent the 401 innermost electrons of the transition metal atom ( $\mathrm{Fe}$ and $\mathrm{Re}$ ) and the basis set of valence double- $\mathrm{z}$ 402 quality for associated with the pseudopotentials known as LANL2DZ [25]. The basis set for the main 403 group elements was 6-31G* $(\mathrm{C}, \mathrm{N}, \mathrm{O}$ and $\mathrm{H})$ [34]. All molecular structures were optimized without 404 symmetry constraints and characterized as minima by vibrational analysis. Polarizabilities and 405 hyperpolarizabilities were computed using frequency-dependent $(u 1 / 40.1 \mathrm{Ha})$ [35]. 


\section{ACKNOWLEDGMENTS}

408

409 A.H.K. and R.A. acknowledge FONDECYT-Chile (Projects 11130443, 1110669 and 1150601),

410 FONDEQUIP EQM 130154 and D.I. Pontificia Universidad Cat】 olica de Valparaíso; J.G. is grateful to

411 the CONICYT for a Doctoral scholarship and D.I.-PUCV and G.A., R.B and C.L acknowledge the

412 financial support from the Direcci] on General de Investigaci] on (DGI) of Spain (Grants n. CTQ2015-

413 6459-C3-1-P and CTQ2015-65040-P).

414 
[1] a) J.M. O'Connor, in: E.W. Abel, F.G.A. Stone, G. Wilkinson (Eds.), Comprehensive

[4] For recent and relevant contributions on half-sandwiches compounds see for instance: a) V. Tirkey, S. Mishra, H.R. Dash, S. Das, B.P. Nayak, S.M. Mobin, S. Chatterjee, J. Organomet. Chem. 732 (2013) 122e129; b) Y.-F. Han, G.-X. Jin, Acc. Chem. Res. 47 (2014) 3571e13579; c) Y.-F. Han, G.-X. Jin, Chem. Soc. Rev. 43 (2014) 2799e2823; d) S.K. Singh, D. Pandey, S. Daya, RSC Adv. 4 (2014) 1819e11840; e) I. R[ emy, P. Brossier, I. Lavastre, J. Besancon, C. Moise, J. Pharm. Biomed. 9 (1991) 965e967; f) X. Wu, J. Xiao, in: P. Dixneuf, V. Cadierno (Eds.), Metal-catalyzed Reactions in Water, 2013, pp. 173e242; g) M. Hapke, C.C. Tzschucke, Angew. Chem. Int. Ed. 52 (2013) 3317e3319; h) W.E. Geiger, Coord. Chem. Rev. 257 (2013) $1459 \mathrm{e} 1471$.

[5] See for instance: a) C. L[ opez, R. Bosque, M. Pujol, J. Sim】 o, E. Sevilla, M. Font- Bardía, R. Messeguer, C. Calvis, Inorganics 2 (2014) 620e648; b) D. Talanc $\square$ on, C. L】 opez, M. FontBardía, T. Calvet, O. Roubeau, Eur. J. Inorg. Chem. (2014) 213e220; c) R. Cortl es, M. Tarrado-Castellarnau, D. Talanc】 on, C. L】 opez, W. Link, D. Ruiz, J. Centelles, J. Quirante, M. Cascante, Metallomics 6 (2014) 622e633; d) D. Talanc】 on, C. L】 opez, M. Font-Bardía, T. Calvet, J. Quirante, C. Calvis, R. Messeguer, R. Cort! es, M. Cascante, L. Baldom】 a, J. Badia, J. Inorg. Biochem. 118 (2013) 1e12 and references cited in these articles.

[6] a) R. Arancibia, A.H. Klahn, G.E. Buono-Cuore, D. Contreras, G. Barriga, C. Olea-Azar, M. Lapier, J.D. Maya, A. Iba nez, M.T. Garland, J. Organomet. Chem. 743 (2013) 49e54; b) R. Arancibia, A.H. Klahn, G.E. Buono-Core, E. Gutierrez-Puebla, A. Monge, M.E. Medina, C. Olea-Azar, J.D. Maya, F. Godoy, J. Organomet. Chem. 696 (2011) 3228e3244.

[7] a) C. L】 opez, R. Bosque, X. Solans, M. Font-Bardia, J. Organomet. Chem. 539 (1997) 99e107; b) H.-M. Li, A.-Q. Feng, X.-H. Lou, Bull. Korean Chem. Soc. 35 (2014) 2551e2554.

[8] a) H. Nishihara, Bull. Chem. Soc. Jpn. 77 (2004) 407e428; b) M. Kurihara, H. Nishihara, Coord. Chem. Rev. 226 (2002) 125e135; c) A.A. Musikhina, I.A. Utepova, P.O. Serebrennikova, O.N. Chupakhin, V.N. Charushin, Russ. J. Org. Chem. 49 (2013) 1191e1194; d) Z.-Q. Hao, J.-F. 
Gong, W.-T. Song, Y.-J. Wu, M.-P. Song, Inorg. Chem. Commun. 10 (2007) 371e375; e) R. Bosque, C. L】 opez, J. Sales, X. Solans, J. Silver, J. Chem. Soc. Dalton Trans. (1996) 3195e3200; f) A.G. Osborne, M. Webba da Silva, M.B. Hursthouse, K.M.A. Malik, G. Opromolla, P. Zanello, J. Organomet. Chem. 516 (1996) 167e176.

[9] a) R. Arancibia, A.H. Klahn, M. Lapier, J.D. Maya, A. Iba nez, M.T. Garland, S. CarrereKremer, L. Kremer, C. Biot, J. Organomet. Chem. 755 (2014) 1e6; b) G. Li, Z. Shi, X. Li, Z. Zhigang, J. Chem. Res. 35 (2011) $278 \mathrm{e} 281$.

[10] a) C. L】 opez, J. Granell, J. Organomet. Chem. 555 (1998) 211e225; b) C. L】 opez, R. Bosque, X. Solans, M. Font-Bardía, J. Organomet. Chem. 535 (1997) 99e105; c) M.M. Abd-Elzaher, W.H. Hegazy, A. El-Din, M. Gaafar, Appl. Organomet. Chem. 19 (2005) 911e916; d) N.G. Shikhaliyev, A.V. Gurbanov, V.M. Muzalevsky, V.G. Nenajdenkob, V.N. Khrustalev, Acta Cryst. E70 (2014) m286em287.

[11] a) C. L】 opez, R. Bosque, J. Arias, E. Evangelio, X. Solans, M. Font-Bardía, J. Organomet. Chem. 672 (2003) 34e42; b) D. Csokas, I. Zupka, B.I. Karalyi, L. Drahos, T. Holczbauer, A. Pallo, M. Czugler, A. Csampi, J. Organomet. Chem. 743 (2013) 130e138; c) E.A. Raspopova, A.N. Morozov, A.O. Bulanov, L.D. Popov, I.N. Shcherbakov, S.I. Levchenkov, V.A. Kogan, Russ. J. Gen. Chem. 82 (2012) 1457e1468; d) P. Krishnamoorthy, P. Sathyadevi, R.R. Butorac, A.H. Cowley, S.P.N. Bhuvanesh, Dalton Trans. 41 (2012) 4423e4438; e) J. Zhang, R. Liu, J. Chem. Soc. Pak. 33 (2011) 356e359.

[12] a) A. Houlton, N. Jasim, R.M.G. Roberts, J. Silver, D. Cunningham, P. McArdle, T. Higgins, J. Chem. Soc. Dalton Trans. (1992) 2235e2241; b) A. Houlton, J.R. Miller, J. Silver, N. Jassim, M.J. Ahmet, Inorg. Chim. Acta 205 (1993) 67e70; c) M. Fuentealba, L. Toupet, C. Manzur, D. Carrillo, I. Ledoux-Rak, J.R. Hamon, J. Organomet. Chem. 692 (2007) 1099e1109.

[13] Recent and relevant contributions on cyrhetrene derivatives: a) I.V. Skabitskii, E.I. Romadina, A.A. Pasynskii, Zh V. Dobrokhotova, S.G. Sakharov, Russ. J. Coord. Chem. 40 (2014) 813 e820; b) G.A. Koutsantonis, P.L. Low, C.F.R. Mackenzie, B.W. Skelton, D.S. Yufit, Organometallics 33 (2014) 4911 e4922; c) T.S. Teets, J.A. Labinger, J.E. Bercaw, Organometallics 33 (2014) 4107e4117; d) Q. Nadeem, D. Can, Y. Shen, F. Yunjun, M. Felber, Z. Mahmood, R. Alberto, Org. Biomol. Chem. 12 (2014) 1966e1974; e) R.D. Young, A.F. Hill, G.E. Cavigliasso, R. Stranger, Angew. Chem. Int. Ed. 52 (2013) 3699e3702.

[14] a) R. Arancibia, F. Godoy, G. Buono-Core, A.H. Klahn, E. Gutierrez-Puebla, A. Monge, Polyhedron 27 (2008) 2421e2425; b) J. Heldt, N. Fischer-Durand, M. Salmain, A. Vessi] eres, G. Jaouen, J. Organomet. Chem. 689 (2004) 4775e4782; c) S. Jones, M. Rausch, P. Bitterwolf, J. Organomet. Chem. 396 (1990) 279e287.

[15] a) D. Sierra, N. Bhuvanesh, J.H. Reibenspies, J.A. Gladysz, A.H. Klahn, J. Organomet. Chem. 749 (2014) 416e420; b) T. Cautivo, H. Klahn, F. Godoy, C. L】 opez, M. Font-Bardía, T. Calvet, E. Gutierrez-Puebla, A. Monge, Organometallics 30 (2011) 5578e5589.

[16] L.A. Tatum, X. Su, I. Aprahamian, Acc. Chem. Res. 47 (2014) 2141e2149.

[17] N. Kolobova, Z. Valueva, M. Solodova, Bull. SSSR Acad. Sci. Div. Chem. 29 (1981) $1701 \mathrm{e} 1705$.

[18] D. Barton, W.D. Ollis (Eds.), Comprehensive Organic Chemistry, Pergamon, Oxford, U.K., 1979. 
[19] a) F.H. Allen, Acta Cryst. Sect. B Struct. Sci. B58 (2002) 380e388; b) Cambridge Crystallographic Data Centre. Available online: www.ccdc.cam. ac.uk/data request/cif (accessed on 24.07.15).

[20] A.-G. Yin, H.-Y. Qian, J. Jia, N. Zhou, L.-Q. Tang, Acta Cryst. Sect. E E62 (2006) o4913.

[21] a) J.-Y. Seo, S.-H. Lee, M. Jazbinsek, H. Yun, J.-T. Kim, Y.S. Lee, I.-H. Back, F. Rotermund, O.-P. Kwon, Cryst. Growth. Des. 12 (2012) 313e318; b) E.I. Choi, K.J. Kim, M. Jazbinsek, J.-T. Kim, Y.S. Lee, P. Günter, S.W. Lee, O.- P. Kwon, Cryst. Growth. Des. 11 (2011) 3049e3055; c) R.A. Howie, T.C. Baddeley, J.L. Wardell, S.M.S.V. Wardell, J. Mol. Struct. 1020 (2012) 16e22; d) O.-P. Kwon, M. Jazbinsek, J.-I. Seo, P.-J. Kim, H. Yun, Y.S. Lee, P. Günter, J. Phys. Chem. C 113 (2009) 15405e15411; e) M.S. Wong, V. Gramlich, C. Boshard, P. Günter, J. Mater. Chem. 7 (1997) 2021e2026.

[22] a) R. Bosque, C. L】 opez, J. Sales, X. Solans, M. Font-Bardía, Dalton Trans. (1994) 735e 745; b) C. L】 opez, R. Bosque, X. Solans, M. Font-Bardía, New J. Chem. 20 (1996) 1285e1292.

[24] a) A.D. Becke, J. Chem. Phys. 98 (1993) 5648e5652; b) C. Lee, W. Yang, R.G. Parr, Phys. Rev. B 37 (1988) $785 \mathrm{e} 789$.

[25] a) W.R. Wadt, P.J. Hay, J. Chem. Phys. 82 (1985) 284e298; b) P.J. Hay, W.R. Wadt, J. Chem. Phys. 82 (1985) 299e310.

[26] M.J. Frisch, G.W. Trucks, H.B. Schlegel, G.E. Scuseria, M.A. Robb, J.R. Cheeseman, G. Scalmani, V. Barone, B. Mennucci, G.A. Petersson, H. Nakatsuji, M. Caricato, X. Li, H.P. Hratchian, A.F. Izmaylov, J. Bloino, G. Zheng, J.L. Sonnenberg, M. Hada, M. Ehara, K. Toyota, R. Fukuda, J. Hasegawa, M. Ishida, T. Nakajima, Y. Honda, O. Kitao, H. Nakai, T. Vreven, J.A. Montgomery Jr., J.E. Peralta, F. Ogliaro, M. Bearpark, J.J. Heyd, E. Brothers, K.N. Kudin, V.N. Staroverov, T. Keith, R. Kobayashi, J. Normand, K. Raghavachari, A. Rendell, J.C. Burant, S.S. Iyengar, J. Tomasi, M. Cossi, N. Rega, J.M. Millam, M. Klene, J.E. Knox, J.B. Cross, V. Bakken, C. Adamo, J. Jaramillo, R. Gomperts, R.E. Stratmann, O. Yazyev, A.J. Austin, R. Cammi, C. Pomelli, J.W. Ochterski, R.L. Martin, K. Morokuma, V.G. Zakrzewski, G.A. Voth, P. Salvador, J.J. Dannenberg, S. Dapprich, A.D. Daniels, O. Farkas, J.B. Foresman, J.V. Ortiz, J. Cioslowski, D.J. Fox, Gaussian 09 (Revission B.1), Gaussian Inc., Wallingford CT, 2010.

[27] M.E. Casida, C. Jamorski, K.C. Casida, D.R. Salahub, J. Chem. Phys. 108 (1998) 4439e4449.

[28] D.D. Perrin, W.L.F. Armarego, Purification of Laboratory Chemicals, fourth ed. ButterwortheHeinemann, Oxford, UK, 1996.

[29] G.M. Sheldrick, SHELXS.A Program for Automatic Solution of Crystal Structure, Univ. Goettingen, Germany, 1997.

[30] G.M. Sheldrick, SHELX97 a Program for Crystal Structure Refinement, Univ. Goettingen, Germany, 1997.

[31] International Tables of X-Ray Crystallography, vol. 4, Kynoch Press, 1974, 99e100 and 149.

[32] APEX2, Bruker AXS Inc., Wisconsin, USAMadison, 2007.

[33] O.V. Dolomanov, L.J. Bourhis, R.J. Gildea, J.A.K. Howard, H. Puschmann, OLEX2: a complete structure solution, refinement and analysis program, J. Appl. Cryst. 42 (2009) 339e341. 
[34] a) P.C. Hariharan, J.A. Pople, Theor. Chim. Acta 28 (1973) 213e222; b) M.M. Francl, W.J. Petro, W.J. Hehre, J.S. Binkley, M.S. Gordon, D.J. DeFrees, J.A. Pople, J. Chem. Phys. 77 (1982) $3654 \mathrm{e} 3665$.

542 [35] J.E. Rice, N.C. Handy, Int. Quantum Chem. 43 (1992) 91e118 and references therein. 


\section{Legends to figures}

547 Figure 1. Representative examples of ferrocenyl and cyrhetrenyl hydrazones described previously $548 \quad[10,11,17]$.

549

550 Scheme 1. Synthesis of compounds $\left[\operatorname{Re}\left\{(\mathrm{h} 5-\mathrm{C} 5 \mathrm{H} 4) \mathrm{eC}(\mathrm{R} 1)^{1 / 1} / 4 \mathrm{NeNHR} 2\right\}(\mathrm{CO}) 3\right]$ with R1 1/4 H (4) or Me 551 (5) and atom numbering system for NMR data.

552

553 Figure 2. Hydrogen bonds promoted by the coordinated ethanol molecules in compound 1 (shown as 554 light blue bonds).

Figure 3. ORTEP plot of the molecular structure of $[\operatorname{Re}\{(\mathrm{h} 5-\mathrm{C} 5 \mathrm{H} 4) \mathrm{eC}(\mathrm{Me}) 1 / 4 \mathrm{NNH} 2\}(\mathrm{CO}) 3](5 \mathrm{c})$.

Hydrogen atoms have been omitted for clarity.

559

Figure 4. UVevisible spectra of compounds $\mathrm{R} 3 \mathrm{CH} 1 / 4 \mathrm{NeNH}(4-\mathrm{NO} 2 \mathrm{C} 6 \mathrm{H} 4)$ with $\mathrm{R} 3$ 1/4 ferrocenyl (3a), cyrhetrenyl (4a) and phenyl (6a) in $\mathrm{CHCl} 3$ at $298 \mathrm{~K}$.

562

Figure 5. Schematic views of the HOMO and LUMO of compounds $\mathrm{R} 3 \mathrm{CH} 1 / 4 \mathrm{NNH}(4-\mathrm{NO} 2 \mathrm{eC} 6 \mathrm{H} 4)$ with R3 1/4 ferrocenyl (3a), cyrhetrenyl (4a), phenyl (6a) or cymantrenyl (7a) and the representation of the main expected transitions in their absorption spectra. 
FIGURE 1

569

570

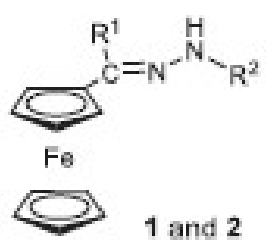

$\mathrm{R}^{1}=\mathrm{H}(\mathbf{1})$ or $\mathrm{Me}(\mathbf{2})$

571

572

573

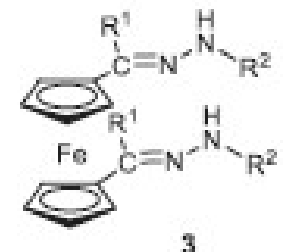

$\mathrm{R}^{1}=\mathrm{H}$ and $\mathrm{R}^{2}=\mathrm{CO}_{2} \mathrm{Me}$ or

$R^{1}=M e$ and $R^{2}=H$

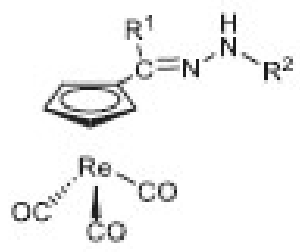

$\mathrm{R}^{1}=\mathrm{H}$ and

$\mathrm{R}^{2}=2,4-\left(\mathrm{NO}_{2}\right)_{2} \mathrm{C}_{6} \mathrm{H}_{3}$ 

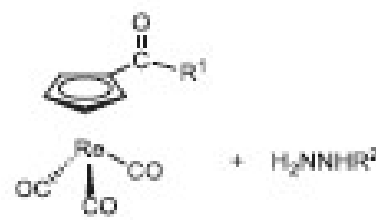

$\mathrm{EIOH} \& \mathrm{MeOH}$

$R^{1}=\mathrm{H}$ or Me $\quad \mathrm{R}^{2}=4-\left(\mathrm{NO}_{2}\right) \mathrm{C}_{2} \mathrm{H}_{4}, \mathrm{C}_{6} \mathrm{H}_{5}$ or $\mathrm{H}$

SCHEME 1

577 


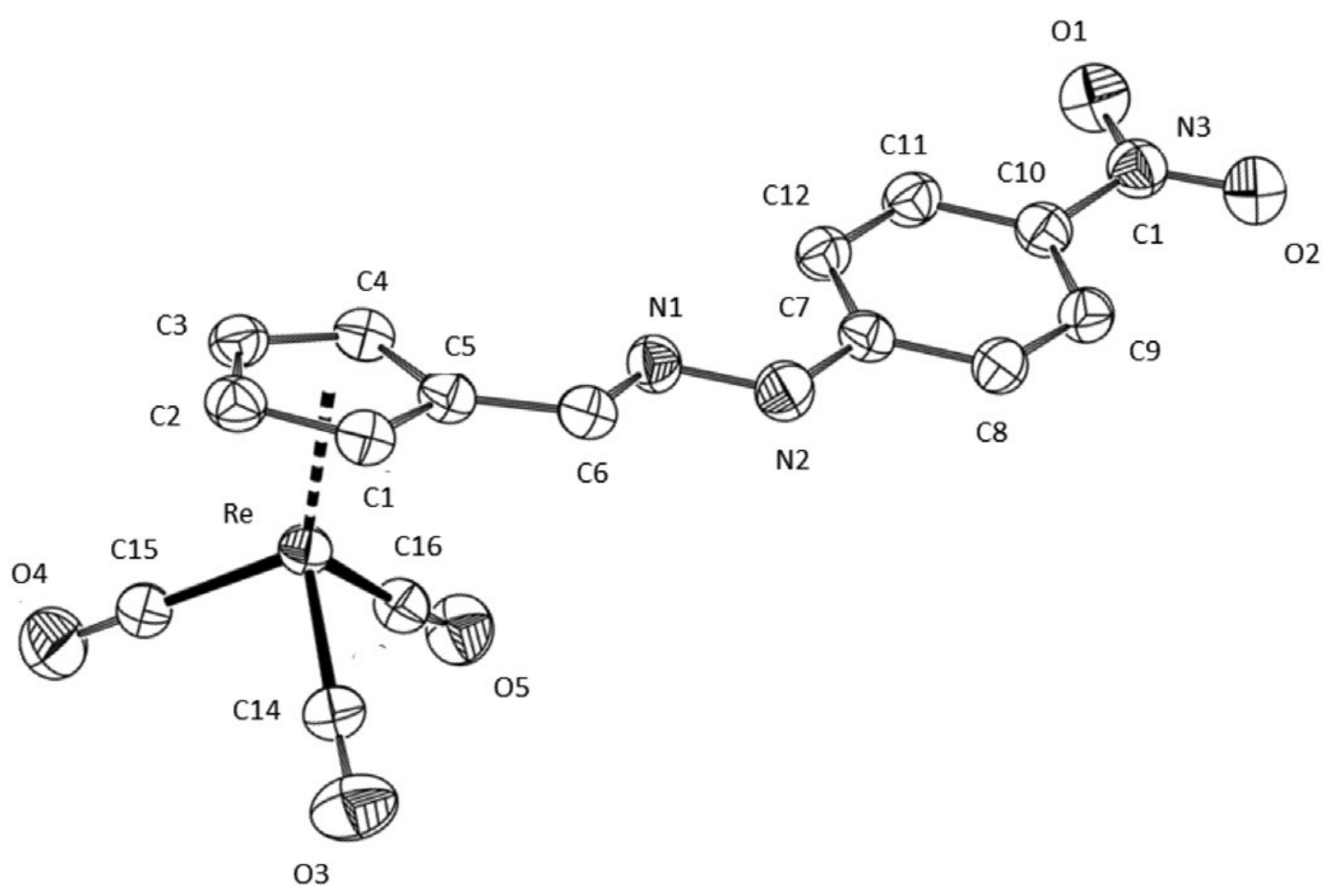




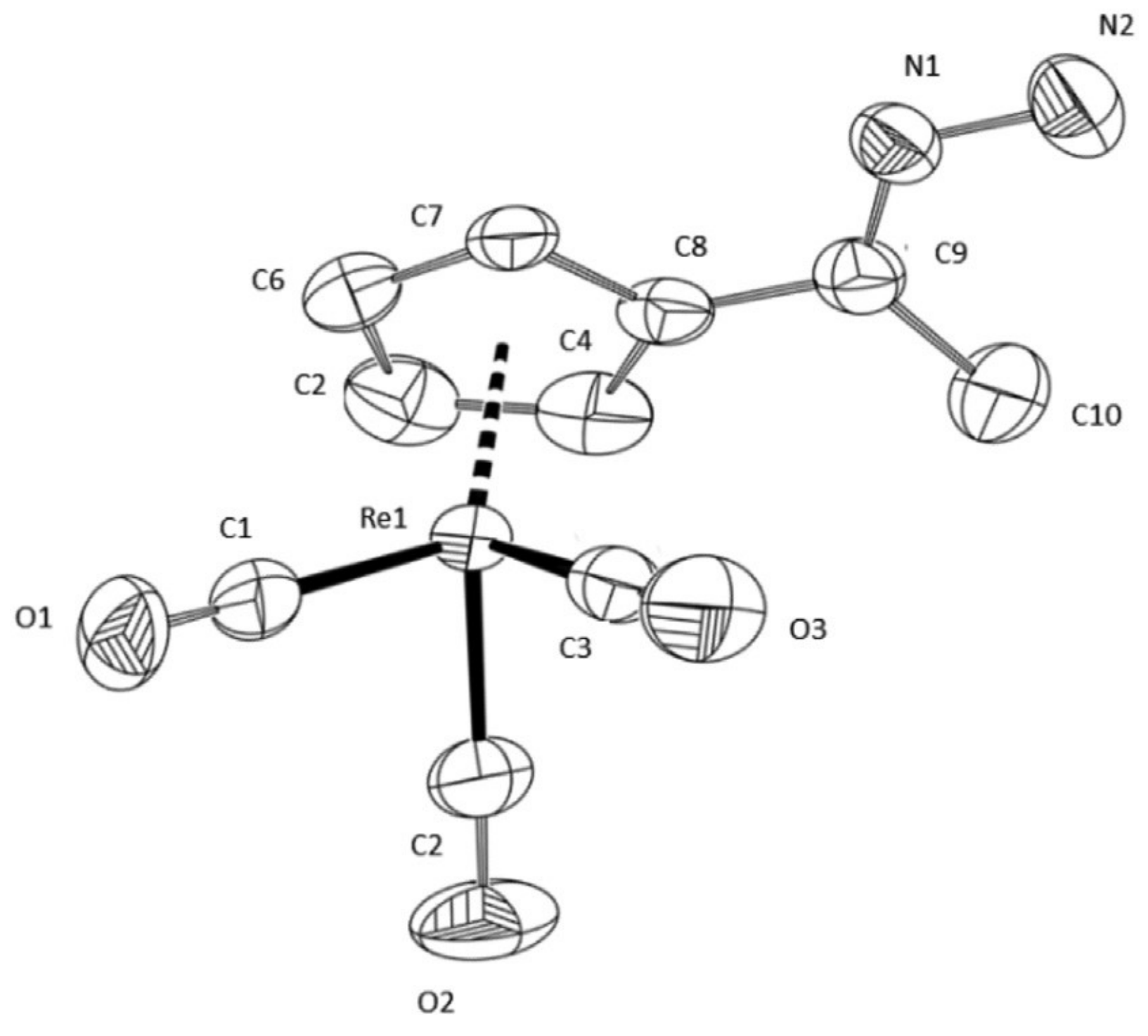




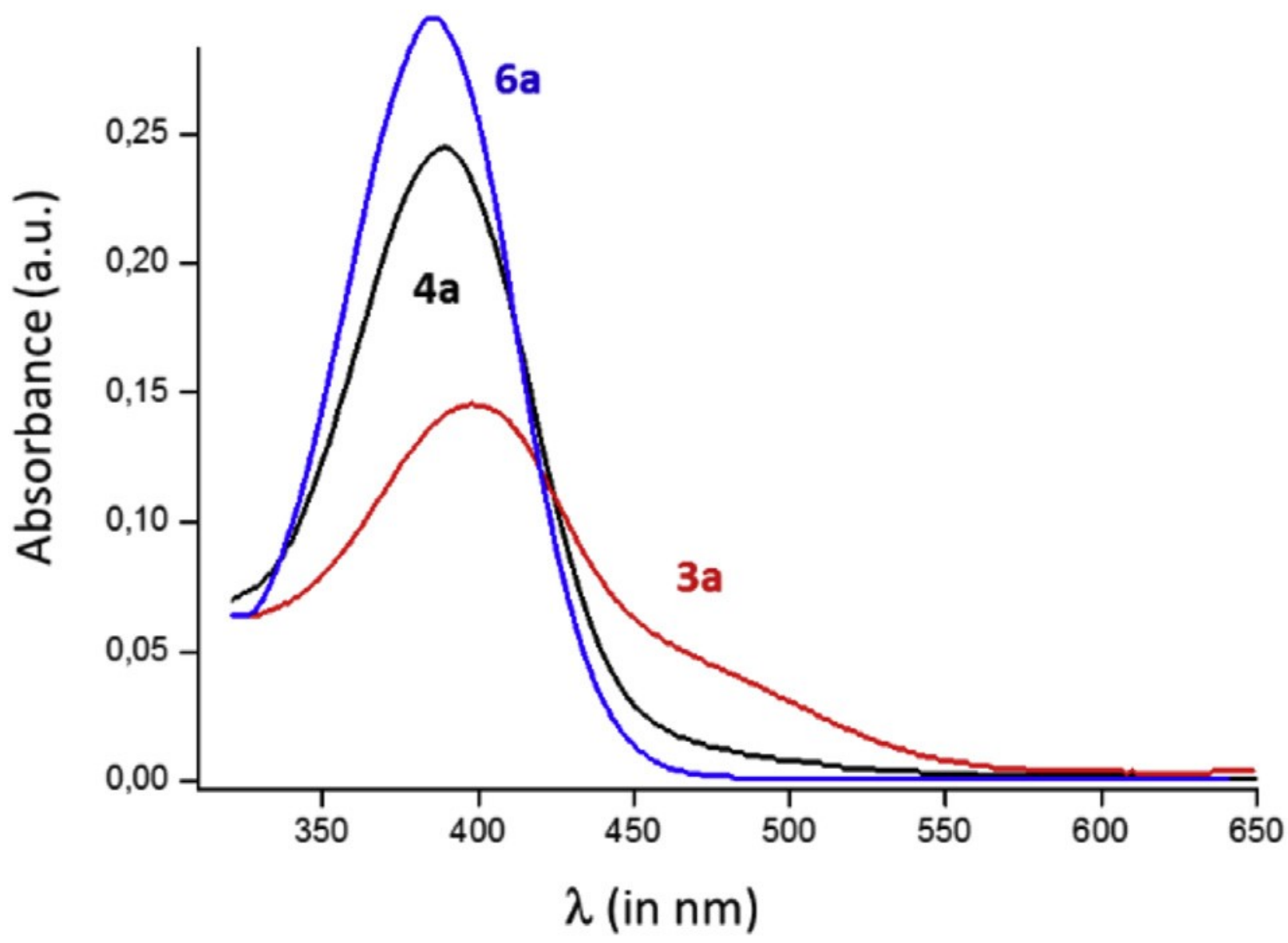


598

599

600

601

602

603
FIGURE 5.

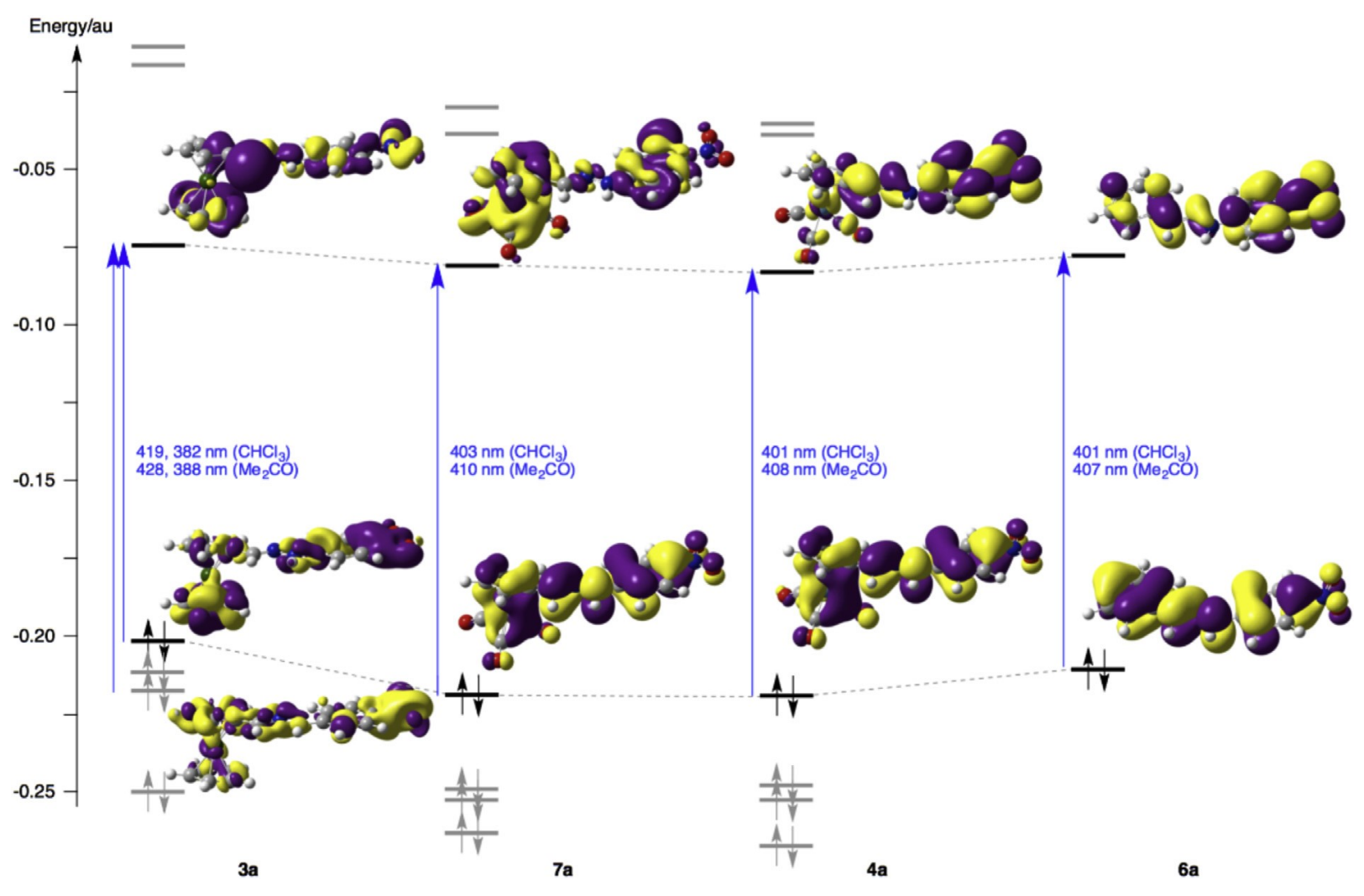


604 Table 1 Selected bond lengths (in $\AA$ ) and angles (in deg.) for compounds $[\operatorname{Re}\{(\mathrm{h} 5-\mathrm{C} 5 \mathrm{H} 4) \mathrm{eC}(\mathrm{H}) 1 / 4$ $605 \mathrm{NeNH}(4-\mathrm{NO} 2 \mathrm{eC} 6 \mathrm{H} 4)\}(\mathrm{CO}) 3],(4 \mathrm{a})$ and $\left[\operatorname{Re}\left\{(\mathrm{h} 5-\mathrm{C} 5 \mathrm{H} 4) \mathrm{eC}(\mathrm{Me}) \frac{1 / 4}{4} \mathrm{NNH} 2\right\}(\mathrm{CO}) 3\right](5 \mathrm{c}) .[\mathrm{Cg}(1)$ 606 represents the centroid of the $\mathrm{C} 5 \mathrm{H} 4 \mathrm{ring}$.

\begin{tabular}{|c|c|c|c|}
\hline & 42 & & sc \\
\hline$R \in-C, 1)$ & $1.945(6)$ & $\mathrm{B} e-\mathrm{Cg}(1)$ & $19703(5)$ \\
\hline Re-(Qring) $)^{2}$ & $2285(14)$ & $R e-Q \operatorname{ting})$ & $2285(14)$ \\
\hline $\mathrm{Re}-\mathrm{C} 14$ & $1.895(6)$ & $\mathrm{Be}=\mathrm{Cl}$ & $1907(5)$ \\
\hline $\mathrm{Re}=\mathrm{Cls}$ & $1.936(6)$ & $\operatorname{Re}-\mathrm{CZ}$ & $1915(5)$ \\
\hline $\mathrm{Re}-\mathrm{C} 16$ & $1.930(6)$ & $\mathrm{Be}-\mathrm{C} 3$ & $1910(4)$ \\
\hline $\mathrm{N} 1-\mathrm{N} 2$ & $1.369(6)$ & $\mathrm{N} 1-\mathrm{N} 2$ & $1368(6)$ \\
\hline $\mathrm{N} 1-\mathrm{C} 6$ & $1.261(7)$ & $\mathrm{N} 1-\mathrm{CO}$ & $1275(5)$ \\
\hline $\mathrm{N} 2-\mathrm{C} 7$ & $1.357(7)$ & $\mathrm{CB}-\mathrm{CO}$ & $1.470(6)$ \\
\hline $\mathrm{CS}-\mathrm{CS}$ & $1.453(8)$ & C) C10 & $1500(6)$ \\
\hline $\mathrm{N} 2-\mathrm{C} 7$ & $1.357(7)$ & & \\
\hline $\mathrm{N3}-01$ & $1.228(7)$ & & \\
\hline $\mathrm{NB}-\mathrm{O}_{2}$ & $1.245(7)$ & & \\
\hline $\mathrm{Cl} 4-\mathrm{Re}-\mathrm{C} 15$ & $91.4(3)$ & $\mathrm{Cl}-\mathrm{Re}-\mathrm{Cl}$ & $8887(9)$ \\
\hline $\mathrm{Cl} 4-\mathrm{Re}-\mathrm{Cl} 6$ & $90.1(3)$ & $\mathrm{Cl}-\mathrm{Re}-\mathrm{C} 3$ & $8945(9)$ \\
\hline $\mathrm{C} 15-\mathrm{Be}-\mathrm{C} 16$ & $91.9(3)$ & $\mathrm{C} 2-\mathrm{Be}-\mathrm{C} 3$ & $89.98(9)$ \\
\hline $\mathrm{Cg}-\mathrm{N} 1-\mathrm{N} 2$ & $1182(4)$ & $\mathrm{Cg}-\mathrm{N} 1-\mathrm{N2}$ & $1182(4)$ \\
\hline \multirow[t]{2}{*}{$01-\mathrm{NB}-\mathrm{O} 2$} & $124.0(5)$ & $\mathrm{CB}-\mathrm{Cg}-\mathrm{N1}$ & $1160(4)$ \\
\hline & & $\mathrm{Cl}-\mathrm{Cg}-\mathrm{N} 1$ & $1245(5)$ \\
\hline
\end{tabular}

609

610

611 
612 Table 2 Experimental Ultravioletevisible spectroscopic data: wavelengths li (in nm), logarithms of the 613 molar extinction coefficients, $\log$ ei (in parenthesis) in chloroform, acetone and acetonitrile, for [R3 $614 \mathrm{CH}] \mathrm{NNH}(4-\mathrm{NO} 2 \mathrm{eC} 6 \mathrm{H} 4)]$ (R3 1/4 ferrocenyl, (3a), cyrhetrenyl (4a) or phenyl (6a).

615

616

\begin{tabular}{|c|c|c|c|c|}
\hline \multirow[b]{2}{*}{$\begin{array}{l}\text { Compound } \\
3 \mathrm{x}^{2}\end{array}$} & \multirow[b]{2}{*}{$\begin{array}{l}\mathbb{R}^{2} \\
\text { Ferrocenyt }\end{array}$} & \multicolumn{3}{|c|}{ Eperimental dartz: $\rangle_{4}(\log a)$ in } \\
\hline & & $\begin{array}{l}\text { Chloroform } \\
398 \text { (4.16) }\end{array}$ & $\begin{array}{l}\text { Acetone } \\
407(435)\end{array}$ & $\begin{array}{l}\text { Acetboitrile } \\
407(4.10)\end{array}$ \\
\hline 42 & Cyrherrenyt & $389(4.39)$ & $395(4.43)$ & $395(4.27)$ \\
\hline $6 a$ & Phemyl & $385(4.47)$ & $389(4.52)$ & $389(4.49)$ \\
\hline
\end{tabular}


619 Table 3. Summary of the results obtained from the computational studies showing. Electronic 620 transitions with greater contributions to the absorption band detected in the UVevis spectra of 621 compounds, together with the position of the bands (1, in $\mathrm{nm})$ determined in gas phase, chloroform and 622 acetone hydrazones 3a, 4a, 6a and 7a (the calculated oscillator strengths are given in parenthesis).

\begin{tabular}{|c|c|c|c|c|c|}
\hline Cmpd & Aasignment & Type & Gas phase & Claroform & Acetone \\
\hline 32 & 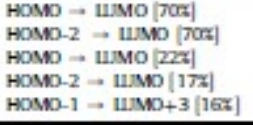 & $\begin{array}{l}\text { IICT } \\
\text { MuCT } \\
\text { MICT } \\
\text { MiCT } \\
d-d\end{array}$ & $\begin{array}{l}384(0.28) \\
342(0.25) \\
365(0.29)\end{array}$ & $\begin{array}{l}419(0.45) \\
382(0.35) \\
361(0.07)\end{array}$ & $\begin{array}{l}428(0.39) \\
388(0.40) \\
363(0.05)\end{array}$ \\
\hline 42 & HOMO - WMO [986] & net & $368(0.88)$ & $401(0.93)$ & $408(0.88)$ \\
\hline $6 \mathbf{3}$ & HOMO - UMO [1005] & ILCT & $366(0.90)$ & $401(0.95)$ & $407(0.91)$ \\
\hline 72 & 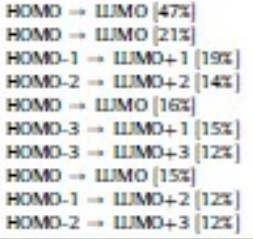 & $\begin{array}{l}\text { IICT } \\
\text { IICT } \\
\text { MiCT } \\
d-d \\
\text { IICT } \\
\text { MUCT } \\
d-d \\
\text { IICT } \\
d-d \\
d-d\end{array}$ & $\begin{array}{l}376(0.42) \\
371(0.19) \\
347(0.16) \\
343(0.11)\end{array}$ & $403(0.87)$ & $410(0.84)$ \\
\hline
\end{tabular}


627 Table 4. Summary of crystallographic data and details of the refinement of the crystal structures of 628 compounds $\left[\operatorname{Re}\left\{(\mathrm{h} 5-\mathrm{C} 5 \mathrm{H} 4) \mathrm{eC}(\mathrm{H}) \frac{1}{4} \mathrm{NeNH}(4-\mathrm{NO} 2 \mathrm{eC} 6 \mathrm{H} 4)\right\}(\mathrm{CO}) 3\right](4 \mathrm{a})$ and $\left[\operatorname{Re}\left\{(\mathrm{h} 5-\mathrm{C} 5 \mathrm{H} 4) \mathrm{eC}(\mathrm{Me}){ }^{1 / 4}\right.\right.$ $629 \mathrm{NeNH} 2\}(\mathrm{CO}) 3](5 \mathrm{c})$.

\begin{tabular}{|c|c|c|}
\hline & 42 & se \\
\hline Crostal sine $/ \mathrm{mm} \times \mathrm{mm} \times \mathrm{mm}$ & $0.2 \times 0.1 \times 0.1$ & $0.312 \times 0.152 \times 0.058$ \\
\hline Anpirical formula & $\mathrm{C}_{1} \mathrm{H}_{10} \mathrm{~N}_{2} \mathrm{O}_{3} \mathrm{Re}$ & $\mathrm{C}_{10} \mathrm{H}_{0} \mathrm{~N}_{2} \mathrm{O}_{2} \mathrm{Re}$ \\
\hline Formula weight & 49845 & 391.39 \\
\hline Cystal sotem & Monoctinic & Manodinic \\
\hline space group & $P z_{1} / \mathrm{c}$ & $P Z_{1}, k$ \\
\hline af $\mathrm{A}$ & $11.582(5)$ & $10911(4)$ \\
\hline$B / A$ & $10920(3)$ & $8.293(3)$ \\
\hline ch & $12448(4)$ & $13.520(2)$ \\
\hline$a=\gamma / \mathrm{dez}$ & 900 & 900 \\
\hline F deg & 9915 & 2220201 \\
\hline$v A^{2}$ & 1555.7(9) & 114879 \\
\hline$z$ & 4 & 4 \\
\hline$T$ & $293(1)$ & 296.15 \\
\hline $\mathrm{A}_{\mathrm{tac}} / \mathrm{mg} \times \mathrm{mm}^{3}$ & 2.128 & 2254 \\
\hline$\mu \mathrm{mmm}^{-i}$ & 7842 & 10576 \\
\hline F(000) & 944 & 7280 \\
\hline Erange for dza collecton / deg. & From 1.78 to 30.30 & From 293 to 26.4 \\
\hline N of collerted reflectoons & 11801 & 24,902 \\
\hline $\mathrm{N}$ of unique reflect [R(int)] & $3765[0.0488]$ & 2336 (00210) \\
\hline N of dxa & 3765 & 2363 \\
\hline $\mathrm{N}$ of parameters & 218 & 147 \\
\hline Coodness of fit on $F^{2}$ & 1.141 & 1.396 \\
\hline Final $R$ indores $[I>2 a(I) \mid$ & $R_{1}=0.032_{2}, w R_{2}=0.0981$ & $R_{i}=0.0152, w R_{2}=0.0445$ \\
\hline Final $R$ indores (all data) & $R_{1}=0.0432, \mathrm{wR}_{2}=0.1022$ & $R_{i}=0.0193, w R_{2}=0.0619$ \\
\hline
\end{tabular}

